\title{
Endowed Molecules and Emergent Organization: The Maupertuis-Diderot Debate
}

\author{
Charles T. Wolfe \\ University of Sydney*
}

\begin{abstract}
In his Système de la nature ou Essai sur les corps organisés (originally published in Latin in 1751 as Dissertatio inauguralis metaphysica de universali naturae systemate, under the pseudonym Dr Baumann), Pierre-Louis Moreau de Maupertuis, President of the Berlin Academy of Sciences and a natural philosopher with a strong interest in the modes of transmission of 'genetic' information, described living minima which he termed molecules, "endowed with desire, memory and intelligence." Now, Maupertuis was a Leibnizian of sorts; his molecules possessed higher-level, 'mental' properties, recalling La Mettrie's statement in L'Homme-Machine, that Leibnizians have "rather spiritualized matter than materialized the soul." But Maupertuis also debated this issue with Diderot, who critiqued this theory in the additions to his 1753 Pensées sur l'interprétation de la nature. Where Maupertuis attributes higher-level properties to his living minima, Diderot argues that these can only be 'organizational', i.e., properties of the whole. At issue here is the degree of commitment to a form of materialism.
\end{abstract}

\section{Keywords}

emergence, materialism, molecule, monad, organisation, Diderot, Maupertuis

In early modern discussions of the nature, function and operation of organic bodies (animal or human), including comparisons of these with various sorts of machines, both real and imagined, it is extremely rare to find distinctions between the two being made on the basis of ontological claims about 'Life' itself or the nature of the frontier separating the living from the non-living, animate matter

\footnotetext{
* Unit for History and Philosophy of Science, University of Sydney, Carslaw F07, Sydney NSW 2006, Australia (c.wolfe@usyd.edu.au).
} 
from inanimate matter. There are accounts of Life as 'vital heat' or fermentation (as in Fernel), as deriving from animal spirits or fibres, and so forth, but almost no explicit claims about the difference between Life and its opposite (with the notable exception of Stahl in his polemic with Leibniz). However, there is a marked shift from discussions of the 'minimum' as a mathematical, physical or metaphysical point to discussions of what we might call 'living minima', the smallest constituents of organic life-from the metaphysics of Bruno and Leibniz to the bio-metaphysics of Gassendi, La Mettrie, Maupertuis and Diderot. (Leibniz himself did not speak of living minima' and indeed avoided describing atoms of substance as 'living', since Life is a property of corporeal entities and conversely, minima are not alive; yet, as I discuss below, his doctrine of the monad was frequently read in the eighteenth century as providing a basis for a vital materialism, or at least a biologically motivated metaphysics. ${ }^{1)}$ In the seventeenth century the term 'molecule' emerges as a name for these living minima, and this essay examines a particular debate on this sense of 'molecule' and vital properties.

The term molecule is derived from the diminutive of the Latin moles, or mass (in Latin, a molecula). Pierre Gassendi used the term molecula synonymously with the Lucretian term semina rerum, with the difference that for Lucretius these 'seeds' were simply atoms, whereas for Gassendi they are composites or compounds of atoms. ${ }^{2}$ Indeed, one should not project the concept of molecule backwards onto early atomism (as for instance an equivalent of concilium), since 'molecule' is the notion of a substantial individual composed of atoms. ${ }^{3}$ Molecules emerge in the chemical vocabulary of the

\footnotetext{
1) Georges Canguilhem, "Note sur les rapports de la théorie cellulaire et de la philosophie de Leibniz, " Appendix II in La connaissance de la vie, revised edition (Paris, 1980), 188.

2) Olivier R. Bloch, La Philosophie de Gassendi. Nominalisme, matérialisme et métaphysique (The Hague, 1971), 252 n.75.

3) Henk Kubbinga, L’histoire du concept de "molécule" (Paris, 2001), 109. For the impact of semina rerum on early modern matter theory, see Hiro Hirai's Le concept de semence dans les théories de la matière à la Renaissance de Ficin à Gassendi (Turnhout, 2005). On the meaning of 'molecule' in seventeenth-century chemistry, matter theory and philosophy, see Bloch, La Philosophie de Gassendi, 252-259; Antonio Clericuzio,
} 
1630s-1640s; while Gassendi appears to have been the first to use the term, he was preceded in articulating a molecular theory of matter by Isaac Beeckman (1588-1637), in notebooks written between 1614 and 1629 (particularly an entry of 1620 discovered by Henk Kubbinga ${ }^{4)}$, where Beeckman's technical term is homogenea physica. But for our purposes it is significant that Gassendi explicitly addresses the 'property' question, that is, do the molecules or 'moleculae' possess sensitive or vital properties?', even though he wavers on the issue. According to some interpreters, Gassendi's molecules do not borrow the properties of sensible objects, whereas others consider that his notion of molecule specifically "helps bridge the gap between sensible qualities and atoms."

The appearance of new conceptual personae ${ }^{7}$ such as the 'molecule' thus creates new worries for natural philosophy, notably the tension between the reductionist definition of minimal entities and the correspondingly anti-reductionist, expanded definition of the attributes of these entities (from Francis Glisson's organic fibres possessing 'appetition' to molecules possessing sensitive and indeed cognitive properties, as discussed here). ${ }^{8}$ This double-barreled definitional

Elements, Principles and Corpuscles: A Study of Atomism and Chemistry in the Seventeenth Century (Dordrecht, 2001), 63-71; Kubbinga, Histoire du concept de "molécule ", chs. 6-8.

4) Kubbinga, "Les premières théories 'moléculaires': Isaac Beeckman (1620) et Sébastien Basson (1621)," Revue d'histoire des sciences, 39 (1984), 215-233, here, 219.

5) Gassendi, Animadversiones in Decimum Librum Diogenis Laerti qui est de vita, moribus placitisque Epicuri, with appendix, Philosophiae Epicuri syntagma (Lyon, 1649), e.g. 398 .

6) Compare Bloch, La Philosophie de Gassendi, 253 to Clericuzio, Elements, Principles and Corpuscles, 65.

7) I borrow this term ("personnage conceptuel”) from Gilles Deleuze \& Félix Guattari, Qu'est-ce-que la philosophie? (Paris, 1991), ch. 3. A conceptual persona can be the cogito for Descartes, Socrates for Plato, or the Antinomies for Kant, but can also be a highly overdetermined, idiosyncratic sense of 'atom', 'molecule' or 'organism'. Put differently, the molecule for Maupertuis or Diderot plays a very different role than it does in the emergence of, e.g., molecular biology as discussed in J.C. Speakman, "The Molecule-The Evolution of a Concept," Philosophical Journal, 2 (1965), 55-75.

8) That the term 'molecule' could carry with it unwanted reductionist baggage is evidenced by Goethe's refusal to employ it in his translation of Diderot's Neveu de Rameau; see Roland Eluerd, "Note sur fibre et molécule dans Le Neveu de Rameau," 
and indeed, ontological problem was at the heart of a debate between two prominent figures of the Enlightenment, Pierre-Louis Moreau de Maupertuis (1698-1759) and Denis Diderot (1713-1784). Maupertuis was a major scientific figure (member of the Académie Royale des Sciences from the age of 25, its director between 1742 and 1745, and most famously President from 1746 onwards of the Berlin Academy of Sciences, appointed by Frederick II) who we primarily associate today with the principle of least action, his expedition to Lapland, which provided experimental confirmation of key tenets of Newtonian physics, and to some extent his reflections on generation and species in works such as the Dissertation physique à l'occasion du Nègre Blanc (1744) and its expanded version, the Vénus physique (1745). ${ }^{9}$ Diderot was the chief editor of the Encyclopédie, a translator of medical works, author of several mathematical essays and, significantly, a regular presence at Guillaume-François Rouelle's chemistry lectures at the Jardin du Roi (now the Jardin des Plantes), between 1754 and $1757 .{ }^{10}$ I shall not discuss the overlapping biographies of Maupertuis and Diderot further here. ${ }^{11}$

Their debate centred precisely on the nature of 'molecules' and their minimal or expanded definition. The textual history of the debate runs as follows: in 1751, Maupertuis published (supposedly

\footnotetext{
L'Information Grammaticale, 52 (1992), 14-16 (thanks to Susan Bernofsky for this example).

9) Much of what we know of Maupertuis' biography comes from his friend Laurent Angliviel de La Beaumelle's admittedly rather hagiographical Vie de Maupertuis (Paris, 1856), written shortly after Maupertuis' death, but published posthumously. The recent studies by Beeson, Terrall and Shank (cited below) are all of high quality, with different emphases.

10) Diderot actually served as secretary during many of the lectures, taking notes and even preparing some of the lectures for Rouelle, which were first published as Introduction à la chymie, manuscrit inédit de Diderot publié avec une notice sur les cours de Rouelle, ed. Charles Henry (Paris, 1887); now available as Cours de chimie de $\mathrm{Mr}$ Rouelle, in Diderot, Euvres complètes, ed. H. Dieckmann, J. Proust \& J. Varloot (Paris, 1975-), vol. IX.

11) A recent discovery worth noting, however, is a letter from Diderot to Maupertuis accompanying a copy of his Lettre sur les aveugles, in 1749. It was published in Anne-Marie Chouillet, "Trois lettres inédites de Diderot," Recherches sur Diderot et l'Encyclopédie, 11:1 (1991), 8-18.
} 
in Erlangen-actually in Berlin) a Latin treatise entitled Dissertatio inauguralis metaphysica de universali naturae systemate, under the pseudonym Dr Baumann. ${ }^{12}$ In 1754, he translated the text into French and published it, now with a more specifically 'biological' title: Essai sur la formation des corps organisés (the translation was signed Abbé Trublet). The final version of the text appeared in French with a title closer to the original, Systeme de la nature, in the 1756 edition of Maupertuis' Euvres. Diderot critically discussed the 'Erlangen dissertation' (and outed its author) in the second edition of his Pensées sur l'interprétation de la nature in 1754 (the first edition had appeared one year earlier), in sections L-LI. Maupertuis replied to Diderot's criticisms in a Réponse aux objections de $M$. Diderot included in the third and final version of his essay, in his 1756 Euvres. ${ }^{13}$

In his System of Nature or Essay on Organized Bodies, Maupertuis asks his readers to imagine a molecule "endowed with desire, aversion and memory." ${ }^{14}$ The debate between Maupertuis and Diderot concerning the nature of what they termed 'molecule' is in fact a debate over "endowment" or "attribution" of properties: should it be applied to the element or the organizational whole? On the surface, this exchange or polemic is also a case of the two authors trading accusations of atheism with each other (for the definition of matter as possessing dynamic, organizational, indeed intellective' properties is of course a dangerous one). But deeper down it is also an opportunity for us to witness a moment of self-delimitation

12) This was also the basis for an anonymous German translation, Versuch von der Bildung der Körpers (Leipzig, 1761), now very rare; cf. Mary Terrall, The Man Who Flattened the Earth: Maupertuis and the Sciences in the Enlightenment (Chicago, 2002), $322 \mathrm{n}$.

13) The edition used is Pierre-Louis Moreau de Maupertuis, Système de la nature. Essai sur la formation des corps organisés and Réponse aux objections de M. Diderot, in Euvres, 2 vols. (Lyon, 1756). The Système and the Réponse are in vol. 2; hereafter cited as Système followed by section number (in Roman numerals), and Réponse, followed by page number. All translations are mine unless otherwise indicated.

14) "douée de désir, d'aversion, et de mémoire" (Système, $₫$ XIV); the term 'endowed' appears in $\$ \$ X X X I$ and LXVI. In sections XIX and XXVII Maupertuis uses instead the term "accorder": matter was "granted" properties. At the end of the book he returns to the language of endowment, speaking of "originarily endowed elements" (\$ LIV, 173). 
of materialism. In the early twentieth century, Paul Janet, one of the first commentators to focus on Diderot philosophically, followed a hint of La Mettrie's, for whom the Leibnizians, "with their Monads, ... spiritualized matter rather than materializing the soul" ("Ils ont plutôt spiritualisé la matière, que matérialisé l'âme"15) and described Maupertuis' 'endowment strategy' as a disguised form of spiritualism. Janet added that Diderot's apparent rebuttal was merely a strategic (one might say 'ideological') one, and that metaphysically his position is actually no different from Maupertuis'. Janet opposes the materialism of the atomists, in which all qualitative changes in the universe are the product of the encounter and combination of primary elements whose essential properties are extension and solidity, to the expanded materialism of Diderot, which he identifies with Maupertuis' endowed molecules, given that in both Diderot and Maupertuis matter possesses additional, mental properties which Janet traces back to Leibniz. ${ }^{16}$

I will briefly examine the Newtonian and especially Leibnizian aspects and background of Maupertuis' thesis, given that his concept of molecule has been described as a 'materialization of the monad', then turn to the core of his discussion of molecules and their properties, after which I consider Diderot's challenge to Maupertuis, that higher-level properties belong to the level of organisation (the overall physiological structure) rather than that of the element. But, as I discuss in closing, their debate involves significant interpretive commitments with respect to materialism, as Maupertuis' project, far from being simplistic, was motivated by the question of how the existence of a living entity could be grounded other than by an appeal to the mystical effects of a life-force; an invocation to the equilibrium existing between the workings of the macrocosm and the microcosm; or a mechanistic reduction to properties such as size, shape and motion? This is where the strategy of the endowed molecule comes into play, the attribution of a self-organizing activity

\footnotetext{
15) Julien Offray de La Mettrie, L'Homme-Machine [1748], ed. A. Vartanian (Princeton, 1960), 149.

16) Paul Janet, "La philosophie de Diderot. le dernier mot d'un matérialiste," The Nineteenth Century, IX (April 1881), 697.
} 
to the molecule, in which "the materials are the workers themselves." ${ }^{17}$ Hence the debate between Maupertuis and Diderot on the status of 'molecules' also highlights some conceptual decisions concerning materialism, emergence and reduction in the context of eighteenthcentury proto-biology and its metaphysical commitments. ${ }^{18}$

\section{The Newtonian and Leibnizian Context}

In order to properly locate the debate between Maupertuis and Diderot, we have to first provide some elements regarding the Newtonian and Leibnizian context, as these large-scale programs in natural philosophy also had direct influence on the formulation of positions concerning generation or development, and reflections on the nature of living beings. It is well known that there was a confounding variety of Newtonianisms operative in the eighteenth century. According to the "taxonomy" suggested by Robert Schofield, ${ }^{19}$ France alone comprised three different strands of 'Leibnizian Newtonianism', those of Maupertuis, Fontenelle and Voltaire, which share a characteristic interpretation of the monad as subject and singularity, as distinguished e.g. from the 'Baconian Newtonianism' which was predominant in the Netherlands with Boerhaave and Musschenbroek, characterized by an emphasis on force and regularity. ${ }^{20}$ Maupertuis is both a major figure of French Newtonianism (his early Discours sur les differentes figures des astres represents the first public defense

\footnotetext{
17) Maupertuis, Système, $\$$ LXI, 180.

18) I discuss the relation between certain projects in the 'proto-biology' of the mideighteenth century, notably natural history in Diderot and Buffon, and ontological considerations (chiefly materialism) in "Cabinet d'Histoire Naturelle', or: The Interplay of Nature and Artifice in Diderot's Naturalism," Perspectives on Science, 17 (2009), 58-77.

19) R.E. Schofield, "An Evolutionary Taxonomy of Eighteenth-Century Newtonianisms," Studies in Eighteenth-Century Culture, 7 (1978), 175-192. For a full account of Newtonianism and its offshoots in France in the eighteenth century, see the remarkable study by J.B. Shank, The Newton Wars and the Beginning of the French Enlightenment (Chicago, 2008).

20) Voltaire conveyed Maupertuis' Newtonian heritage, which he approved on deistic grounds, in the nickname "Sir Isaac Maupertuis" (Voltaire, Euvres complètes, ed. L. Moland [Paris, 1877-1882], XXXV, 54).
} 
of attractionism in the Paris Academy, where Cartesian ideology still dominated) and perhaps the main figure involved in successively grafting more and more Leibnizian elements into this framework. Diderot's more Baconian heritage is manifest in the very title of the work discussed here, Pensées sur l'Interprétation de la Nature, that is, Thoughts on the Interpretation of Nature (recall that the full title of Bacon's main work is Novum Organum sive de interpretatione naturae). But Newtonianism itself, whether by using gravity and attraction as an analogical basis for studying vital properties, or in the more quantitative vein of the English 'medical Newtonians' such as Archibald Pitcairne, offered various possibilities for deriving a system of generation.

However, Maupertuis explicitly states that Newtonian attraction does not sufficiently account for organic phenomena, or even "the simplest chemical operations." 21 The laws of movement are not sufficient to explain the reproduction of living beings_-which is his motivation for writing the Système. In the earlier Vénus physique he had formulated the hypothesis that natural organisms were formed by attraction alone; now, in the context of an epigenetic theory, he acknowledges that the force of attraction alone cannot sufficiently account for the production of specifically organized bodies: "A blind, uniform attraction distributed throughout the parts of matter would not explain how these parts arrange themselves to form even the simplest organized body. . . . Why shouldn't they unite at random?"22 That is, the same force of gravitation-attraction which controls the behavior of bodies in space governs the formation of organic bodies. However, as the force of attraction is transformed, in Maupertuis' terminology, into affinity, it loses the characteristics of the simple mechanical phenomenon of the Newtonian model and gains "Leibnizian" qualities (justifying Schofield's category of 'Leibnizian Newtonianism'). Maupertuis will add properties to his living minima which they would not possess in a strict Newtonian model. His

\footnotetext{
21) Système, $\$$ III, 141.

22) "Une attraction uniforme et aveugle répartie dans toutes les parties de la matière, ne saurait servir à expliquer comment ces parties s'arrangent pour former le corps dont l'organisation est la plus simple. . . . Pourquoi ne s'unissent-elles pas pêle-mêle?” (Maupertuis, Système, $\$$ XIV, 146-147).
} 
interest is to see a kind of Thinking at work-an informational model of genetic transmission as the transmission of non-material 'coding' or 'content'-but our concern for now is simply to map out his arguments for the "endowed molecule."

The Newtonian context in its different forms could be hybridized with Leibnizian elements, whether as a 'vitalized' physics or a more explicitly radical materialist project, given that "both [Leibnizianism and Newtonianism] could be imagined as offering a philosophy of nature that made innate material forces in bodies the causal agent in a deterministic universe governed by impersonal, mathematical laws." ${ }^{23}$ Leibnizian metaphysics and theories of generation thus had a great impact on eighteenth-century thought, and are frequently considered to be major influences in the formulation of Diderot's materialism among others. ${ }^{24}$ In a pattern familiar from the controversies over Cartesian physiology (when some of Descartes' disciples such as Regius steered his system towards materialism) or thinking matter (when Locke's skeptical approach was deliberately misread as an explicitly materialist credo), Leibniz's insistence that one not confuse or blend the physical and the metaphysical levels of his system; that mechanical science and monadic metaphysics were distinct, was disregarded..$^{25}$ Thus his idea of the organism as a 'machine of nature' was turned into a biological concept: even the vitalist physician Théophile de Bordeu named monads (along with Buffon's organic molecules) in his list of the main "hypotheses on the elements of bodies," ${ }^{26}$ in a trend extending at least as far as Johannes Müller in the nineteenth century. To reiterate an earlier point in part, Leibniz himself does not hold that there are 'basic' organic components, since machines of nature are, after all, machines

\footnotetext{
23) Shank, The Newton Wars, 433.

24) See (with some reservations) Yvon Belaval, "Note sur Diderot et Leibniz" and "Diderot lecteur de Leibniz ?", in his Études leibniziennes (Paris, 1976) and for more extensive textual consideration, but unreliable interpretive claims, Claire Fauvergue, Diderot lecteur et interprète de Leibniz (Paris, 2006).

25) Gottfried Wilhelm Leibniz, Philosophischen Schriften, ed. C.I. Gerhardt, 7 vols. (reprint, Hildesheim/New York, 1978), IV, 434f., VII, 343; Mathematische Schriften, ed. C.I. Gerhardt, 7 vols. (reprint, Hildesheim/New York, 1962), VI, 134f., $242 \mathrm{f}$.

26) Théophile de Bordeu, Recherches sur les maladies chroniques (Paris, 1775), 333-334.
} 
to infinity—although this did not prevent 'vital' or otherwise materialist readings of his concept-but of course, he acknowledges that he was inspired by living beings for his concept (much as Aristotle's concept of substance is inspired by biological entities without being itself biological). ${ }^{27}$

On the occasion of the Berlin Academy's essay competition on monads in 1748 - which was to give rise to bitter institutional infighting, as the Academy was torn between Leibnizians such as Wolff and Newtonians such as Euler, with unfortunate effects such as Maupertuis' inappropriate usage of his authority to censure the work of the Wolffian Johann Samuel König, who had linked Maupertuis' principle of least action to Leibniz ${ }^{28}$ - there was a great deal of 'naturalized' interpretation of the monad concept, including Maupertuis but also Condillac's 1748 prize essay for the competition. ${ }^{29}$ Maupertuis' own brief essay on the topic declares that "Monads might in principle be nothing other than the primary elements of matter, endowed with perception and force," 30 a description that is rather close to Diderot's in his Encyclopédie entry "Leibnizianisme": the monad is "the real atom of nature" ("l'atome réel de la nature" 31 , itself closely related to the "sensing and living molecules" he will postulate in Le Rêve de D'Alembert. Hence Canguilhem could declare with some justice that "in France in the eighteenth century, it was

\footnotetext{
27) Thanks to Stephen Gaukroger and Justin E.H. Smith for helpful discussions on this point.

28) See Terrall, The Man Who Flattened the Earth, 292-309; Shank, The Newton Wars, 474-475.

29) Condillac's election to the Academy in 1749 may have owed a lot to Maupertuis, to whom he wrote on Christmas Day of that year to express his pleasure and gratitude at being elected (Condillac, Euvres philosophiques, ed. G. Le Roy [Paris, 1947], II, 533). His prize essay was only properly identified and published recently: Les monades, mémoire présenté à l'Académie de Berlin, critical edition by Laurence Bongie, in Studies on Voltaire and the Eighteenth Century, 187 (1980).

30) “Les monades pourraient n'être dans leur principe que les éléments premiers de la matière, dotés de perception et de force" (Maupertuis, Sur les monades, Letter VIII in Lettres de Maupertuis [Dresden, 1752], 57). For discussion see Annie Ibrahim, "Matière inerte et matière vivante. La théorie de la perception chez Maupertuis," Dix-huitième siècle, 24 (1992), 95-103.

31) Diderot, Euvres complètes, VII, 692.
} 
above all through Maupertuis that the philosophy of Leibniz informed and oriented speculation concerning the growth and structure of living beings." 32

Now, Maupertuis himself was not a self-proclaimed Leibnizian, not least for the institutional reasons alluded to above. And his own explicit contribution to the debate on monads, the eighth of his Lettres, entitled Sur les monades, ${ }^{33}$ a 'casual' piece in the manner of Voltaire, is somewhat of an obfuscation. But one needs only to compare Maupertuis' statement quoted above, that the monad could very well be understood as the basic element of matter, endowed with perception and force, with the views of Samuel Formey, the Perpetual Secretary of the Berlin Academy, to see that Maupertuis' molecules look suspiciously like 'materializations of the monad'; as Roselyne Rey put it, "what was a principle of change within substance has become a property of living matter." ${ }^{34}$ Formey devoted an essay to the topic of matter theory in response to some of the submissions for the Berlin Academy of Sciences prize competition on monads: the 1747 Recherches sur les éléments de la matière. Targetting thinkers such as the anonymous author of the Gedancken von den Elementen der Cörper... (Berlin, 1746), Formey argues that deliberately or not, they confuse the system of the monads with that of the divisibility of matter. ${ }^{35} \mathrm{He}$ insists that the genuine "elements of matter" are not accessible through microscopes ${ }^{36}$; the reality of these elements must be demonstrated metaphysically (like Leibniz did for Clarke). Atoms cannot be these elements because they are merely bits of extension, not simple beings ("êtres simples") possessed of a "principle of action" 37 which explains change in Nature. The experiential fact that bodies can be active or passive

\footnotetext{
32) Canguilhem, "Note sur les rapports," 188.

33) Lettres de Maupertuis, 55-57.

34) Roselyne Rey, "L'âme, le corps et le vivant," in Mirko Grmek, ed., Histoire de la pensée médicale en Occident, vol. 2 : De la Renaissance aux Lumières (Paris, 1997), 122. 35) Samuel Formey, Recherches sur les éléments de la matière, $\$$ II, in Formey, Mélanges philosophiques, vol. 1 (Leyden, 1754), 263-265.

36) Ibid., $\$$ XII, 277.

37) Ibid., \ LIV, 327.
} 
is explained, Formey continues in proper Leibnizian fashion, by their possessing such a principle, which is in fact force.

Thus Maupertuis' notion of the molecule belongs to a broader context of materialist and/or biologically oriented interpretations of Leibnizian monads. A desire to account for the phenomena of generation leads him to look for forces and properties other than basic Newtonian attraction, to account for the regular production of organized bodies, i.e., organisms.

\section{Maupertuis' Argument}

Maupertuis introduces his argument for 'endowment' in section XIV of his book:

If we wish to be able to formulate anything about this, even if we can only conceive it through analogy, we must have recourse to a principle of intelligence, to something akin to what we call desire, aversion, memory. ${ }^{38}$

"This" is the question, why do the parts unite to form a body, and especially, why this body rather than another? Notice the admission that this can only be conceived "through analogy." Maupertuis adds later on that the analogy is intended to complement trials through experience, when dealing with species other than our own, and, moving towards increasingly abstract or remote cases, he explains that God did endow the smallest parts of matter with properties like ("semblable") what we refer to as "desire, aversion and memory" in us (it is not clear on what basis he selects these three properties, which sound faintly monadological but could also be derived from a variety of other sources). ${ }^{39}$ Lastly, he adds that we should not worry about attributing a principle of intelligence to matter, for it is in fact not an intelligence like our own. ${ }^{40}$

\footnotetext{
38) 'Si l'on veut dire sur cela quelque chose qu'on conçoive, quoiqu'encore on ne le conçoive que sur quelque analogie, il faut avoir recours à quelque principe d'intelligence, à quelque chose de semblable à ce que nous appellons désir, aversion, mémoire" (Système, $\$$ XIV, 147, reiterated in $\$ \$ X X V I I I, 155-156$ and XXXI, 157-158, and again in $₫$ LXVI, 183 (with God now explicitly named as the 'donor').

39) Ibid., \$ LIV, 172.

40) Ibid., $\$$ LXII, 181.
} 
Yet Maupertuis nonetheless fears that attributing a kind of intelligence to matter would be viewed as tantamount to materialism, precisely in the vein of Lockean thinking matter. And he was not mistaken: the attribution of generative, organizational and intellective powers to matter earned him the epithet of 'materialist' (or Spinozist, or hylozoist) in a variety of responses ranging from an anonymous review in the Bibliothèque raisonnée to very visible statements by the likes of Rousseau in the "Profession de foi du vicaire savoyard" (1762) and Kant in The Only Possible Proof in Support of the Demonstration of the Existence of God (1763). ${ }^{41}$ After all, shortly after Maupertuis published (anonymously) the first, Latin version of the Système de la nature, Fontenelle famously warned in his Théorie des tourbillons cartésiens that attributing attraction to matter was a small step away from granting it the power to think:

The Newtonians can say that, just as bodies only move by the will of God, it is possible that by this same will they mutually attract one another; but the difference is a major one. In the first case, God's will merely enacts an essential property of matter, its mobility, and inclines its natural indifference towards rest or motion, towards motion. But in the second case, how could bodies have a disposition to attract each other by themselves? God's will would have no relation to their nature, and would be wholly arbitrary, which is quite contrary to the order of the universe witnessed everywhere. If we grant this arbitrariness, we destroy any philosophical proof of the spirituality of the soul. God could just as well have granted thought to matter, as attraction. ${ }^{42}$

\footnotetext{
41) Anonymous review of the Vénus physique, Bibliothèque raisonnée, 35 (1745), 312. For Rousseau's blanket dismissal of the idea of the 'living molecule', see "Profession de foi du vicaire savoyard," in Emile, ou de l'éducation, Euvres complètes, ed. B. Gagnebin \& M. Raymond, vol. 4 (Paris, 1969), 575; Kant specifically targets Maupertuis' molecules possessing memory, desire, aversion, even if by analogy only, as a major case of the dangers of hylozoism (Der einzig mögliche Beweisgrund zu einer Demonstration des Daseins Gottes, as cited by John Zammito, "Kant's Early Views on Epigenesis: The role of Maupertuis," in Justin E.H. Smith, ed., The Problem of Animal Generation in Early Modern Philosophy [Cambridge, 2006], 317-354, here, 343).

42) Bernard Le Bovier de Fontenelle, Théorie des tourbillons Cartésiens; avec des réflexions sur l'attraction [1752], Réflexions sur la théorie précédente, $\$$ III, in Euvres de Fontenelle (Paris, 1829), III, 71, emphasis mine. For brief discussion of the last sentence, see Pierre Sudaka, "Lintervention de Maupertuis dans la philosophie," in Olivier Bloch,
} 
How does Maupertuis avoid the charge of materialism? Rather than claiming that the property of thought belongs to matter in toto, he makes an excursus into animal-machines and reminds the reader that the earliest (and most orthodox) theologians granted intelligence to animals. Now, he adds, thanks to the microscope, we discover smaller and smaller animals every day, which establishes that animals are aggregates (literally "heaps," "amas") of matter of varying sizes. Why not grant, then, that intelligence might be present in infinitely small parcels of matter? ${ }^{33}$ This is sufficient to dispel theological worries, in his view, so he now turns to the properly philosophical objection of dualism, according to which body and soul are separate substances, and intelligence belongs to the soul $(\$$ XXI, 150). Maupertuis is willing to accept the distinction between extension and thought as self-evident but he adds that these are properties of a subject "whose specific essence is unknown to us" ( $\mathbb{S}$ XXII, 151). If we wish to attend empirically to natural phenomena ( $\$$ XXIII, 152), specifically the formation of organized bodies, and we apply the rule of the reduction of phenomena to the smallest number of principles, we see that the Cartesian principles are insufficient ( $\$$ XXV, 154). Maupertuis quickly adds that he is not calling Genesis into doubt-Scripture adequately explains "how all these bodies emerged out of nothingness" (ibid.) - but rather the rules of the preservation of the world after creation ( $\$$ XXVII, 155). In order that bodies as they exist today can have formed, Maupertuis suggests that matter must possess properties other than merely physical ones: we must "grant it some degree of intelligence, desire, aversion, and memory" ( $\$$ XXVII, 155 ; in his response to Diderot he adds "instinct" ${ }^{44)}$. Diderot will explicitly reject this attribution of 'mental' properties to material entities.

But notice that Maupertuis is not so much trying to engage in high metaphysics, postulating some kind of higher intelligence embedded in matter; he is endeavoring to explain how an organism becomes

ed., Actes de la journée Maupertuis (Paris, 1975), 61; David Beeson, Maupertuis: An Intellectual Biography (Oxford, 1992), 51.

43) Maupertuis, Système, $₫$ XVI, 148; $₫$ XVIII, 149.

44) Réponse aux objections de M. Diderot, 215. 
what it is, how a certain quantity of matter goes through a series of transitions to become an organized body, such as a fetus. ${ }^{45}$ In order to do so, he attributes self-organizing properties to the molecule. This act of attribution is one possible materialist approach to the question of generation or development, whereas the other emphasizes the primacy of organizational features, as we will see with Diderot; but both have in common the rejection of Cartesian matter theory, for matter in this new configuration (in which both Leibniz and Spinoza play a role, as they do explicitly for someone like John Toland ${ }^{46)}$ is already a bearer of its own internal dispositions, starting with movement and moving upwards from there to cognitive properties. The molecule is not describable in terms of passive, Cartesian matter qua extension but rather active, Leibnizian matter ${ }^{47}$; even in Spinoza there was no recognition of a particular potency or drive of living entities (the conatus has nothing particularly 'vital' about it), a potential which Maupertuis, Diderot and others witnessed in Leeuwenhoek and Hartsoeker's spermatozoa, Réaumur's chrysalids, Bonnet's aphids, Trembley's polyps, or the 'animalcules' of the anguillard, Needham. ${ }^{48}$

Let us return to Maupertuis' train of argument. The notion of matter containing within it an intelligent principle actually presupposes a notion of intelligence, Maupertuis points out: a unified,

\footnotetext{
45) Maupertuis asks from what stage onwards the fetus possesses a soul, and wisely dismisses the question as an artificial one ( $($ LIX, 178).

46) John Toland, Letters to Serena (London, 1704), Letter V, "Motion essential to Matter," 163-239. Tristan Dagron, in his new study Toland et Leibniz. Linvention du néo-spinozisme (Paris, 2009), argues that Toland is less a materialist interpreter of Spinoza than he is an interlocutor of Leibniz's who develops in debate with the latter a new, 'endowed' concept of matter.

47) Jacques Roger, Les sciences de la vie dans la pensée française au XVIII' siècle [Paris, third edition 1993], 479. As Cassirer put it, "In his approach to the concept of the monad Maupertuis does not attempt to conceive the fundamental units of which all natural processes consist as metaphysical points—as Leibniz had done-but as physical points. In order to arrive at these units we need not depart from the corporeal world as such, but we must enlarge the concept of matter in such a way that it does not exclude the basic facts of consciousness" (The Philosophy of the Enlightenent, trans. Fritz C.A. Kölln \& James P. Pettegrove [Princeton, 1951], 88).

48) Cf. Système, $\$ \mathrm{XL}, 162$.
} 
indivisible notion of intelligence (he does not give a particular definition of what he means by this, but the Cartesian echoes are fairly clear, just as the monadological overtones are at other times). But why can't we see that our own intelligence actually exists in a graded set of degrees? Our levels of conscious awareness are variable, in both senses of the term: they are changing, but also able to extend over a wide spectrum ranging from sleep to wakefulness $(\$$ LXII, 180-181). In other words, we should not worry about attributing intelligence to the elements of matter, since our own 'total' intelligence is manifold and changing. And what is the contrary view, which denies any intelligence to the constituent 'atoms' and indeed reduces the workings of the universe to atoms and chance? Epicurean atheism, the system of the "freethinkers (libertins) of the present day" ( $\$$ LXIV, 182-183). This is less an instance of the inextricability of biological and theological concerns in early modernity than it is a deliberate strategic move on Maupertuis' part: when advancing a controversial view about the mind, organic bodies, intelligence, liberty and necessity, and so forth, it is extremely useful to be able to counterpose this view to a recognizably 'Epicurean', 'Spinozist' or otherwise materialist position. ${ }^{49}$ So the attribution of a form of intelligence (instinct, memory, etc.) to matter or rather the 'molecule' is not meant as a self-consciously materialist affirmation by Maupertuis (who was comfortable using Epicurean-Lucretian arguments against final causes in nature in earlier publications such as the 1750 Essai de cosmologie). The fact that living matter possesses a kind of potential (formative or generative, like a Bildungstrieb or nisus formativus) is chiefly for him evidence of a kind of Mind or Intelligence. Without such a principle, the body could not develop as an autonomous whole; all bodies would have been continuously developing or fully formed since Creation.

But the predominant (call it 'Cartesian') conception that intelligence has to be distinct from the properties of a material component,

\footnotetext{
49) Anthony Collins thus distinguishes his (quite radical) determinism from the Epicurean doctrine of atoms and chance in his Philosophical Inquiry concerning Human Liberty (London, 1717); Joseph Priestley suggests in his Disquisitions Relating to Matter and Spirit (London, 1777) that compliance with substance dualism is a Catholic tenet, not part of core Christian commitments.
} 
even a living material component such as the molecule, needs further rebuttal. According to this predominant view, our 'sense of unity', our 'inner sense' (a notion going back to Augustine ${ }^{50)}$ cannot have a manifold, composite origin. Maupertuis elegantly suggests that when all these elements, each possessing its own desire and perception, are gathered together as a unity, the result is an individual perception which is stronger and more perfect than any particular elementary perception, ${ }^{51}$ since these have lost their "particular sense of self" 52 - a kind of holism. This is why we have no direct experience of the origin of the elements of which we are composed, "our origin must be lost to us" (ibid.). A given quantity of elementary parts will always produce an equivalent quantity of concurrent perceptions: the same temperament, aversions, and talents ... ${ }^{53}$

All of this sounds rather far removed from Maupertuis the 'forerunner of genetics' or of Darwinism, as he was once known. But within the same discussion he turns to the informational aspect of this notion of 'elementary perceptions' and suggests that it explains why certain cognitive or intellectual traits of a parent are present in the mind ("soul") of a child, or why a well-bred hunting dog produces offspring who are equally good at hunting. ${ }^{54}$ Maupertuis considers a great deal of genetic variety-he studied various cases of hereditary anomalies, from albinos to the Ruhe family in Berlin, which exhibited the condition of polydactyly (specifically six fingers on one hand) for several generations of the descendants of Elisabeth Horstmann, and he calculated the chances of it being hereditary ${ }^{55}$ but what it implies for him in this context is that neither chance, nor divine design are the relevant sorts of explanations for the combination of stability and variety that he witnesses therein.

\footnotetext{
50) Augustine, De libero arbitrio, II, 3, 5.

51) David Beeson sees this as a "major concession to materialism" (Maupertuis, 212).

52) Maupertuis, Système, $\$$ LIV, 172.

53) Maupertuis continues ( $\$$ LVII, 176) with a rather obscure consideration of the possibility of education (and ethics) given this determined genetic structure.

54) Ibid., \$ LVI, 174.

55) Lettre XIV, "Sur la génération des animaux," in CEuvres, vol. 2, p. 267; in the translation appended to Michael Hoffheimer, "Maupertuis and the Eighteenth-Century Critique of Preexistence," Journal of the History of Biology, 15 (1982), 142.
} 
Granted, "the first production of any system is a miracle." ${ }^{56}$ But God does not have the resources to produce a miracle each time a new body is produced. There must be a specific formal explanation for the workings of organic bodies (Maupertuis' particular concern is with biological development, not with organismic laws or the principle that distinguishes living from non-living matter). How could other systems of generation explain phenomena that he has witnessed such as resemblance through heredity, monsters, hybrids or métis? ${ }^{57}$ A recurrent anomaly such as the presence of six fingers on one hand across several generations, refutes preformationism, the system according to which the child is fully contained (formed) in paternal semen, or in the maternal ovum. On Maupertuis' view, it is an accidental material arrangement which is then repeated as a pattern, until a stronger pattern replaces it. ${ }^{58}$ But he is not specifically concerned with the mode in which the seminal principles are arranged. Other processes of generation may exist as well, governing the growth of "other animalcules which can be found swarming in most fluids." ${ }^{59}$ Neither parthenogenesis nor spontaneous generation present any difficulty for his system: if there is such a thing as spontaneous generation, it does not affect Maupertuis' thesis that a new individual is produced by the arrangement of seeds (semences) in combination. ${ }^{60}$ We can treat the original production as miraculous, ${ }^{61}$ but if we consider molecules as possessing the three key properties of desire, aversion and memory, then we can understand the process by which they combine in regular, coherent ways: "In matter's initial state of fluidity, every element placed itself in

\footnotetext{
56) Ibid., $\$ X X X, 157$.

57) Ibid., $\$$ XXXII, 158.

58) Ibid., $\$ \$ X X X V I I, 160-161$, XLV, 164. Jacques Roger considers this to be "the first complete statement of generalized transformism” (Les sciences de la vie, 484).

59) Maupertuis, Système, $\$$ XL, 162.

${ }^{60)}$ Ibid., $₫$ XLVI, 165 . In most species, these reproductive elements are to be found in certain secretions; but apparently in other species, these éléments propres à sunir d'une certaine manière are to be found either within a single individual, or outside of the individual-to-be-produced (ibid.). Maupertuis refers ( $\$$ XLVII, 168) to Buffon, Histoire naturelle II, 8-9 for an analysis of the same fact with plants.

61) Ibid., $\$$ XXX, 157.
} 
the most suitable location to form bodies which no longer show traces of their formation." ${ }^{62}$

A key feature of Maupertuis' account of genetic transmission is what he calls, self-consciously acknowledging the extent to which he cannot escape analogy in his vocabulary, the memory of the molecule. Is this a kind of conscious memory or more of one might term a 'positional' memory? It is clear that for Maupertuis the 'endowed' molecules possess a kind of positional memory combined with a drive ("desire," "instinct") to combine with other molecules in structurally coherent ways. As Shirley Roe puts it, "By 'remembering' their former locations and by possessing an instinct to unite, the seminal particles would be able to arrange themselves into an embryo in the proper fashion." ${ }^{63}$ Even the sterility of mules can be explained thus: the particles retain the memory, the 'habit' so to speak of their former location in a mare or a donkey, but their being located in the new formation (a mule) has the consequence that the organism cannot reproduce. But in fact the memory of Maupertuis' molecules is not strictly positional, as François Jacob observed: if we compare them with Buffon's "organic molecules," the memory possessed by Maupertuis' endowed molecules is indistinguishably material (spatial, positional) and psychic, whereas that possessed by Buffon's organic molecules is restrictively positional and structural. ${ }^{64}$ Diderot himself considers that Buffon's organic molecules are easier to accept scientifically because Buffon does not attribute 'psychic' properties to them such as intelligence or memory.

In sum, Maupertuis' concept of molecules 'endowed' with higherlevel properties is a distinctive claim, contrasting both with a classic atomistic model in which basic elements ("éléments bruts") lacking any form of intelligence or appetition form more complex bodies throughout the universe, in and through their chance encounters,

\footnotetext{
62) Ibid., $₫$ LI, 170.

63) Shirley Roe, Matter, Life, and Generation. Eighteenth-century Embryology and the Haller-Wolff Debate (Cambridge, 1981), 15; similar summary in James L. Larson, Interpreting Nature: The Science of Living Form from Linnaeus to Kant (Baltimore, 1994), 136.

64) François Jacob, La logique du vivant. Une histoire de l'hérédité (Paris, 1970), 92-93.
} 
and with a voluntaristic 'design' claim in which a Supreme Being, distinct from matter, makes use of the elements of matter like an architect uses stone to make buildings. In Maupertuis' vision, the elements themselves, "endowed with intelligence, arrange and unite themselves in order to fulfill the aims of the Creator." 65

\section{Diderot's Criticisms}

Diderot rejects the idea of endowed molecules, at least in its essential form as stated by Maupertuis. ${ }^{66} \mathrm{His}$ arguments focus on the positions expressed in sections LII, LIII, and LIV. In order to challenge Maupertuis' hypothesis, which he accepts at the level of its "empirical" benefits but not as an overall "speculative" claim, he seeks to push it as far as it can go; whether we agree with Maupertuis or Buffon, Diderot says, what is important is the extent to which these hypotheses on generation contribute to the progress of "experimental physics, rational philosophy, and the discovery and explanation of the phenomena of organization" ${ }^{67}$ - with the latter term referring to biological structure. In addition he is ironic about Maupertuis' fears of falling into materialism (or of being taken as such).

The problem with Maupertuis, for Diderot, was that his molecules seemed to have been spiritualized (recalling La Mettrie's distinction), whereas he, Diderot, wanted to materialize the realm of the spiritual (i.e. the mental): first there is matter and motion, and gradually, through corpuscular arrangements of increasing complexity-which he terms "organization" - the phenomena or rather faculties of desire, aversion, memory, etc., are added on. Now, this seems rather mechanistic in contrast to Maupertuis; and indeed at

\footnotetext{
65) Maupertuis, Système, $₫$ LXVII, 183-184.

66) Marx W. Wartofsky, "Diderot and the Development of Materialist Monism," Diderot Studies, 2 (1952), 292-293 is still one of the best commentaries on the topic. (It was reprinted in Wartofsky, Models. Representation and the Scientific Understanding, Boston Studies in Philosophy of Science, vol. 48 [Dordrecht, 1979].)

67) Pensées sur l'interprétation de la nature (Paris, 1753/1754), \$XII; hereafter Pensées followed by the section number (and page numbers in the Euvres complètes).
} 
this point Diderot introduces the "dull sensitivity" (sensibilité sourde) by means of which all molecules have their place, or fit into place. To be precise, Diderot allows for two properties: this rudimentary form of sensitivity, and an "automatic restlessness" (inquiétude automate) which leads the molecules into a variety of possible locations. ${ }^{68}$ In combination, these two 'basic' properties are meant to account for the same variety of organic forms as Maupertuis' multiple properties (desire, aversion, intelligence etc.). Maupertuis' basic properties are more 'teleological' than Diderot's, and overall are too excessive: Diderot thinks that Maupertuis could have stopped at mass, motion-and this "mute" or "dull" sensitivity. Of course, Diderot wavers on the exact locus of this sensitivity: does it belong to matter as a whole, or only to organized matter?

In some texts, Diderot suggests that "sensitivity or touch is common to all beings," attributes sensitivity to the molecule, or to matter as a whole; in his entry "Leibnitzianisme" in the Encyclopédie, he brings together Aristotle's entelechy, Leibniz's monads, and "sensitivity as a general property of matter." ${ }^{\prime 9}$ But in others, such as the 1765 Letter to Duclos, he denies that sensitivity can be a property of a molecule, specifically because it can only be a property of matter itself, and complicates the issue further by introducing a distinction between "inert" sensitivity and "active" sensitivity. ${ }^{70}$ In $L e$ Rêve de d'Alembert, Diderot presents the unity of the person as the result of "the gradual apposition of several sensitive molecules"

68) Diderot, Pensées, $\$$ LI, in Euvres complètes, IX, 84. A variety of texts of this period, whether 'chemical' (Rouelle, Venel), 'medical' (Sauvages, Bordeu) or other (Maupertuis and here Diderot) describe molecules as agitated by an internal motion, in some cases viewed as characteristic of 'Life'. Thus François Boissier de Sauvages, in his 1752 Dissertation sur les médicaments qui affectent certaines parties du corps humain plutôt que d'autres, explains that medicines work on the body because of the internal agitation of their molecules (in Sauvages, Les Chefs-d'ouvre de Monsieur de Sauvages, ou Recueil de dissertations qui ont remporté le prix dans différentes Académies [Lausanne and Lyon, 2 vols., 1770], II, 20.)

69) Diderot, Éléments de physiologie, in Euvres complètes, XVII, 308; "Leibnitzianisme," Encyclopédie, IX (1765), 371.

70) “Lettre à Duclos," October 10 1765, in Diderot, Correspondance, ed. Georges Roth, vol. 5 (Paris, 1959), 141.

71) Diderot, Rêve de D'Alembert, in Euvres complètes, XVII, 134. 
"each sensitive molecule possessed its self before the application; but how did it lose it, and how, out of all these losses, did the consciousness of a whole result?" (ibid.) An answer to this question, why the molecules connect to one another, is provided by Maupertuis: there is a kind of agreement or 'contract' between them such that the perception of each element is combined with the perceptions of the others. The result, as we have seen, is "an individual perception which is stronger and more perfect than any particular elementary perception." 72

It is in this context that Maupertuis introduces the metaphor of the bee-swarm, which will prove to be one of the most successful and evocative images of organic unity in the eighteenth century, in various renditions, some more organismic, some more mechanistic: "Thus an army seen from a distance might appear to us as a great animal; thus a bee-swarm, when the bees are assembled and united on the branch of a tree, only presents to our gaze a body lacking any resemblance to the individuals which composed it." ${ }^{73}$ While Diderot also makes use of this image of organic unity as a composite of living parts, he emphasizes somewhat disingenuously that for Maupertuis it illustrates the 'totalizing' principle that all molecules form a whole with a unified perception-a sense of the whole (le Tout) which, Diderot claims, will "force [Maupertuis] to admit that the world can be God." ${ }^{.4}$ Indeed, the accusation that a strong

\footnotetext{
72) Système, $\$$ LIV, 172; compare the overtly political metaphor used in the earlier Vénus physique, when Maupertuis asks if instinct, "like the spirit of a Republic," is "present throughout the parts of the body, or, like in a Monarchic state, if it only belongs to one indivisible part?" (Vénus physique, final chapter, \$ II , in Euvres, vol. 2, 132).

73) Système, $\$$ LI, 170-171. Bordeu's 1751 Recherches anatomiques sur les glandes also presents this image (but the book was written over several years prior to this date); the vitalist physician Ménuret de Chambaud discusses Bordeu and Ménuret's respective claims to priority in the Encyclopédie article "Observation"; finally, Diderot returns to the image at length in his 1769 opus Le Rêve de d'Alembert. For comparison between these authors' usage of the image of the bee-swarm, see Colas Duflo, "Diderot et Ménuret de Chambaud," Recherches sur Diderot et sur l'Encyclopédie, 34 (avril 2003), 25-44; Charles Wolfe \& Motoichi Terada, "The 'Animal Economy' as Object and Program in Montpellier Vitalism," Science in Context 21:4 (December 2008), special issue on Medical Vitalism in the Enlightenment, 537-579, here, 550-554.

74) Diderot, Pensées, $\$$ L, in CEuvres complètes, IX, 82.
} 
notion of the Whole entails the collapse of individual perceptions and thus individuality itself into a general perception was a standard argument against Spinoza, running at least from Bayle and Leibniz to German Idealism.

Diderot refers to Maupertuis' position provocatively as "the most alluring (séduisante) kind of materialism," 75 referring specifically to the notion I have referred to here as 'endowed molecules'. As we have seen, he deems these molecules to be over-laden with properties, and prefers a system based on a more minimal "dull sensitivity" (which of course is simply another form of materialism, perhaps a purer one). So on the one hand Diderot radicalizes Maupertuis' position, towards an "alluring" materialism (while ironically reproaching him for falling into this trap); on the other hand he looks for a less metaphysically invested form of the same 'vital materialist' position. By seeking to force Maupertuis to take a stance on the notion of the Whole, it is possible that Diderot is trying to achieve an even more total victory for materialism: because either Maupertuis accepts it (and then Spinozism is true) or he rejects it, so that the universe is not an ordered whole (and then Lucretianism is true). ${ }^{76}$

\section{Maupertuis' Response}

From the outset ${ }^{77}$ Diderot had declared that he intended to push Maupertuis' hypotheses to their ultimate ... or absurd conclusion. He claims that it is necessary to do so, in order to unmask the "terrible consequences" of the Erlangen Doctor's theory. Maupertuis responds that if one were not already convinced of the sincerity of Diderot's religious beliefs, one might suspect that his intention is not so much to overturn his own theory as to "himself draw these consequences he calls terrible from it." ${ }^{78}$ Indeed, if we open the

\footnotetext{
75) Ibid., $\$$ LI, in Cuvres complètes, IX, 84.

76) François Duchesneau appears to suggest something like this in La physiologie des Lumières. Empirisme, modèles et théories (The Hague, 1982), 253.

77) Diderot, Pensées sur l'interprétation de la nature, $\$$ L, in Euvres complètes, IX, 77.

78) Maupertuis, Réponse, 197.
} 
works of respected authors who are no longer living, such as Descartes or Malebranche, and apply Diderot's method of inferring consequences, the result would be that "Genesis is denied, and the freedom and power of God are nowhere to be found." ${ }^{9}$ In any case, Maupertuis adds, all systems are fallible, because they are finite ${ }^{80}$ His retort to Diderot is that the latter's materialism is a form of systematic abstraction just like Cartesianism. ${ }^{81}$ While this may appear merely polemical, it is nevertheless the expression of a moderate skepticism which characterizes Maupertuis' argumentation throughout his intellectual career, not just in response to Cartesianism (or materialism) but also as a way of "leveling the playing field" 82 when confronted by the competing claims of Newtonians and Leibnizians, in his twofold capacity as a natural philosopher and the President of the Berlin Academy.

But the key component in Maupertuis' response to Diderot is a notion which is equally important in Diderot's own thought, that of the Whole (le Tout). ${ }^{83}$ It is because both Maupertuis and Diderot are committed to a notion of the universe as a substantial Whole that they are 'neo-Spinozists' in a broad sense (in addition to the specific, idiosyncratic sense manifest, e.g. in Diderot's article "Spinosistes" in the Encyclopédie, in which so-called "modern Spinozists" are described as holding a version of the theory of biological epigenesis), to use the term coined by Paul Vernière. ${ }^{84}$ In this integrated,

\footnotetext{
79) Ibid., 198.

80) Ibid., 199-200.

81) Beeson, Maupertuis, 251. Maupertuis makes this point at greater length in his Letter VII, 'On Systems' (Lettres de Maupertuis, 48-54).

82) Shank, The Newton Wars, 287.

83) For an excellent brief presentation see Jean-Claude Bourdin, "Tout, le tout," in Bourdin, Annie Ibrahim et al., eds., L'Encyclopédie du Rêve de D'Alembert (Paris, 2006), 364-368.

84) Paul Vernière introduced the influential (and controversial) category of 'neoSpinozism' in his Spinoza et la pensée française avant la Révolution (Paris, 1954, $2^{\text {nd }}$ edition 1982); he defines it as a form of holist materialism founded on the life sciences rather than on a priori metaphysical speculation (529). At least Diderot's entry "Spinosistes" corresponds to this description. Vernière describes Diderot and Maupertuis as neo-Spinozists in an editorial note to his edition of Diderot, Euvres philosophiques (Paris, 1961), 229. For more extensive discussions of Diderot's usage of Spinoza and
} 
causally closed universe, there is no particular demarcation between dead and living matter.

What is this notion of the Whole and how does it function in Maupertuis' response?

First, according to Maupertuis, Diderot is vague in his usage of terms like "the Whole." 85 If (a) the whole, le tout, is that which "leaves nothing beyond itself" (ne laisse rien au delà), the question of whether or not the universe is a whole or not is irrelevant to the issue; if (b) a whole, un tout, is a regular edifice, an assemblage of proportionate parts, the previous question can be answered affirmatively or negatively. ${ }^{86}$ If the answer is No, God's existence will not be put into question, any more than it was by pious authors such as Malebranche, for whom the universe was a heap of ruins. ${ }^{87}$ If the answer is Yes, it does not follow that this "copulation of perceptions" necessarily extends to the entire Universe (ibid.). According to Diderot, all systems ultimately are founded on reasoning by analogy; this is mistaken in Maupertuis' view, since analogy will never establish truth or falsehood (a somewhat odd position to take for someone whose most significant description of the molecule explicitly relied on analogy).

Second, certain modern philosophers, following the principle that Nature makes no leaps, view matter as one single continuous piece (bloc). If Diderot meant this notion of continuity when he spoke of the Whole, one should reply that reason and experience prove that there are vacuums in Nature; bodies are merely scattered in space. ${ }^{88}$ Maupertuis insists that regardless of the degree of continuity of the universe, any real difference between le continu and le disséminé will simply be a matter of distance between parts: hence

Spinozism, see Alexandre Métraux, "Über Denis Diderots physiologisch interpretierten Spinoza," Studia Spinozana, 10 (1994), 121-134 and John Zammito, "Naturalizm XVIII Wieku. Spinozyzm w Filozofiach nauki Diderota i Herdera," in Rozum i S'wiat: Herder i filozofia XVIII, XIX i XX wieku, eds. Marion Heinz, Maciej Potepa, Zbigniew Zwolin'ski (Warsaw, 2004), 117-146.

85) Maupertuis, Réponse, 204.

86) Ibid., 205.

87) Ibid., 206.

88) Ibid., 207. 
his cherished elements will continue to exist. Degrees of density exist for our perception. The microscope refutes the claim of absolute continuity, since it shows distance between apparently homogeneous, compact parts. ${ }^{89}$ (Maupertuis does not seem to have undertaken microscopic observations himself, relying instead on the reports of Needham's "infusoires.")

If one follows another sense of Diderot's tout, i.e., Spinoza's God, then Dr Baumann will assuredly deny that the universe is a whole. ${ }^{90}$ Maupertuis refuses to believe that there is anything perilous in his system of elementary perceptions, and as such is happy to extend it also to the largest bodies in the universe, without thereby making gods of them. He criticizes Diderot for believing that he, Maupertuis, is wrong in attributing perception to matter, while on his part attributing sensation to matter; with some degree of justification (at least Diderot requires a good deal of interpreting here) he considers this to be a lapse into dualism. ${ }^{91}$ There is of course a running ideological thread here, which would be straightforward if it were simply a matter of the two authors trading accusations of atheism, materialism and Spinozism, as they do, but is more complicated because it involves at least three other rhetorical dimensions. Namely, (a) praise for the very same ideas: Diderot describes 'Dr Baumann's' "Erlangen dissertation" as being "full of new and singular ideas," and recommends that "we read his work to learn how to reconcile the boldest philosophical ideas with the deepest respect for religion" ${ }^{22}$; (b) Diderot also suggests that Maupertuis should 'stick to biology' and not address the status of the soul: "if Dr Baumann only kept his system to its rightful limits, and applied his ideas strictly to the

89) Ibid., 207-208.

90) Ibid., 208.

91) Ibid., respectively 209, 212. For an attempt to systematize Diderot on this issue (arguing that he is a substance monist but a functional dualist for whom there are levels of complexity in sensitivity), see Jean Deprun, "Lanthropologie de Diderot: monisme métaphysique et dualisme fonctionnel," in A. Mango, ed., Diderot. Il politico, il filosofo, lo scrittore (Milan, 1986), 115-122.

92) Diderot, Pensées, $\$$ L, in CEuvres complètes, IX, 79. On the ideological dimension see Aram Vartanian, "Diderot et Maupertuis," Revue internationale de philosophie 38:148149 (1984), 46-66 - more as a 'stimulant' than as a guide to Maupertuis or Diderot. 
formation of animals..." ${ }^{93}$; (c) lastly, as we have seen, he also deliberately 'overdetermines' what Maupertuis intended.

\section{Stakes of the Debate}

Maupertuis' molecules are a significant 'conceptual persona' in the history of vital minima, whether this history is construed as a series of developments and complexifications in matter theory, or a more qualitative, metaphysically laden pre-history of Lavoisian chemistry. They are of course not alone in the relevant natural-philosophical landscape; in addition to Gassendi's semina rerum and Glisson's appetitive, perceiving fibres mentioned at the beginning, a more extensive study would have to discuss Buffon's organic molecules, Albrecht von Haller's fibres and the various treatments of molecules in Stahlian and post-Stahlian chemistry, notably Gabriel-François Venel's "molécules intégrantes," which he distinguishes from the 'masses, forces and qualities' which are basic for physics. ${ }^{94}$ Admittedly, Venel's chemical definition of living bodies as "mucous bodies" (corps muqueux) which undergo "fermentation" itself resolves these bodies into "masses of organic molecules" (amas de molécules organiques). ${ }^{95}$

Should we then grant particular significance to the idea of attribution or endowment of properties? What exactly is the nature of the material substrate of the attributes of desire, memory, aversion, intelligence and instinct? It is not obvious exactly at which level Maupertuis wishes to articulate his theory: is it a system of generation among others, or a 'meta-theory' of generation? He clearly wishes to express these ideas at a greater level of abstraction than some others, while however invoking empirical data. But he also is more ambitious than he needs to be, as Diderot will put it, and seeks to provide a metaphysical mooring-point for his theory of generation. Diderot appears to be the more methodologically sophisticated of

\footnotetext{
93) Diderot, Pensées, $\$$ LI, in CEuvres complètes, IX, 83.

94) Venel, "Chymie," Encyclopédie, III (1753), 411b, 416a. On chemistry in the mideighteenth century in France, see Kubbinga, Histoire, 440-441.

95) Venel, "Muqueux, corps (chymie)," Encyclopédie, X (1765), 865b.
} 
the two, since rather than attributing a host of properties to the element (molecule) directly, he recognizes that the sensitivity of an organic being must be explained in terms of its nervous system and the way in which it relates to the individuality or selfhood of this being. In addition, he does not "endow" matter with what Maupertuis himself called "non-physical" attributes ${ }^{96}$ - that is, phenomenological properties of matter.

Maupertuis' endowed molecules ultimately tend towards a homuncular theory of an infinitely small entity which possesses (even if only by analogy) the attributes we are familiar with from our own experience. Each molecule possesses a "self" and memories of this "self" which gradually fade away as the molecule enters into increasingly complex arrangements, in a totality, the sense of self of which is stronger than that of the element. Philosophically, this seems open to the charge of pan-psychism (as stated at least as early as Janet's essay in the late nineteenth century). But if understood in heuristic terms, the idea of attributing informational properties to organic, organized matter is ironically more 'realistic' than Diderot's vast organic cosmogony. Conversely, the idea that the properties of complex living beings can only be attributed to the whole, the organisation, the network, seems much more convincing to us than Leibnizian, homuncular argumentation (however naturalized). Emergentist theories, to use contemporary terminology, ${ }^{97}$ have the advantage that they take into account the properties of the constituent parts, including in a reductionist sense, but then seek to study the consequences of their interaction.

96) Système, $\$$ XXVIII, 155.

97) For a brief application of the term 'emergentism' to Maupertuis, see T.S. Hall, Ideas of Life and Matter. Studies in the History of General Physiology, vol. 2 (Chicago, 1969), 26-28. For a more extensive account of eighteenth-century models of organic life as 'organizational' (and thus beyond the split between reduction and emergence), see Wolfe and Terada, “The Animal Economy,” 558-574. 